\title{
EFEK TERAPI SPRAY AND STRETCH TERHADAP NYERI PADA SINDROM NYERI MIOFASIAL OTOT TRAPESIUS ATAS
}

\author{
Novina Santoso \\ Joudy Gessal \\ Bagian Ilmu Kedokteran Fisik dan Rehabilitasi Fakultas Kedokteran \\ Universitas Sam Ratulangi/BLU RSUP Prof. Dr. R.D. Kandou Manado \\ Email: novinasantoso@gmail.com
}

\begin{abstract}
Myofacial pain syndrome is a group of muscle disorders characterized by trigger points in one or more muscles associated with pain, muscle spasm, stiffness, weakness, limited range of motion, and local autonomic dysfunction of the skin. This study aimed to evaluate the effect of spray and stretch therapy on upper trapezius myofascial pain. This was an experimental pre- and post-study, performed in the Medical Rehabilitation Department of Prof. Dr. R. D. Kandou Hospital Manado in June and July, 2012. Participants were seventeen patients with upper trapezius myofascial pain, consisting of ten females and seven males. All participants were treated with spray and stretch therapy for five consecutive days, then were evaluated for pain reduction by using the visual analog scale (VAS) every day after each session. The results showed that there was significant pain reduction measured by using VAS $(P<0.05)$ from day 2 . The reduction of VAS on day 3 and day 4 was highly significant $(P<$ 0.01 ). Conclusion: There was a significant reduction of upper trapezius myofascial pain treated with spray and stretch therapy from day 2 to day 5.
\end{abstract}

Keywords: upper trapezius myofascial pain, spray and stretch therapy, visual analog scale (VAS)

\begin{abstract}
Abstrak: Sindrom nyeri miofasial merupakan kelompok kelainan otot dengan ciri adanya trigger point pada satu atau lebih otot disertai keluhan nyeri, spasme otot, kekakuan, kelemahan, keterbatasan luas gerak sendi, dan disfungsi otonom lokal pada kulit. Penelitian ini bertujuan untuk mengetahui efek terapi spray and stretch terhadap nyeri miofasial otot trapezius atas. Penelitian ini bersifat eksperimental dengan metode pre and post study, dan dilakukan di Instalasi/SMF Rehabilitasi Medik BLU RSUP Prof. Dr. R. D. Kandou Manado bulan Juni dan Juli 2012. Subyek penelitian terdiri dari 17 pasien dengan sindrom nyeri miofasial otot trapesius atas, terdiri dari 10 pasien perempuan dan 7 laki-laki. Perlakuan yang diberikan ialah terapi spray and stretch selama 5 hari berturut-turut, dan dilakukan evaluasi penurunan nyeri dengan menggunakan visual analog scale (VAS) setiap hari setelah pemberian terapi. Hasil penelitian memperlihatkan bahwa selama 5 hari perlakuan didapatkan penurunan nyeri miofasial otot trapesius atas diukur dengan VAS yang bermakna $(P<0,05)$ sejak hari ke-2, dan penurunan nyeri pada hari ke-3 dan ke-4 dengan hasil sangat bermakna ( $P$ $<0,01)$. Simpulan: Penurunan nyeri yang bermakna pada sindrom nyeri miofasial otot trapesius atas dengan terapi spray and stretch terjadi pada terapi hari ke-2 sampai hari ke-5.
\end{abstract}

Kata kunci: nyeri miofasial otot trapesius atas, terapi spray and stretch, visual analog scale (VAS)

Sindrom nyeri miofasial terdiri dari kelompok kelainan otot dengan ciri adanya titik yang hipersensitif disebut trigger point pada satu atau lebih otot dengan keluhan berupa nyeri, spasme otot, kekakuan, kelemahan, keterbatasan luas gerak sendi, 
dan disfungsi otonom lokal pada kulit (vasokonstriksi, respon pilomotor, hipersekresi). ${ }^{1,2}$ Sampai saat ini di kalangan kedokteran Indonesia sindrom nyeri miofasial dengan trigger point belum begitu dikenal, meskipun beberapa pendekatan terapinya telah banyak dilakukan. ${ }^{3}$

Landasan teoritis patofisiologi sindrom nyeri miofasial yang banyak diterima ialah "integrated trigger point hypothesis" berdasarkan Simons et al., ${ }^{1}$ yang menyatakan disfungsi primer ialah adanya peningkatan pelepasan asetilkolin yang tidak normal pada motor endplate akibat beban otot yang berlebihan. Kondisi tersebut menyebabkan depolarisasi membran post-junctional serat otot secara terusmenerus sehingga terjadi pelepasan ion kalsium dari retikulum sarkoplasma bersamaan dengan pemakaian ion kalsium (yang berikatan dengan troponin $\mathrm{C}$ ) untuk memicu ikatan aktin dan miosin sehingga terjadi pemendekan sarkomer yang terus menerus. Berbagai perubahan tersebut akan meningkatkan kebutuhan energi. Disamping itu, kontraksi serat otot yang terus menerus menyebabkan penekanan pembuluh darah setempat sehingga menurunkan persediaan oksigen dan nutrisi. Adanya peningkatan kebutuhan energi pada kondisi melemahnya persediaan energi menyebabkan terjadinya krisis energi setempat. Hal ini menyebabkan elevasi sensitizing substances seperti bradikinin dan 5-HT yang dapat berinteraksi dengan saraf sensorik dan otonom. Selanjutnya, pelepasan substansi neuroaktif seperti substansi $\mathrm{P}$ dan glutamat dapat berperan pada pelepasan asetilkolin yang eksesif dari saraf terminal sehingga terjadi suatu vicious cycle. ${ }^{2}$

Setiap orang pernah mengalami beberapa tipe nyeri otot. Nyeri otot kronik dan berulang terdapat pada 10-20\% populasi berusia $\geq 18$ tahun di Amerika Serikat. Nyeri otot atau miofasial dapat menjadi nyeri kronik yang tidak saja menyebabkan keterbatasan gerak tetapi juga berperan untuk terjadinya depresi, gangguan tidur, dan kelainan psikososial. ${ }^{3}$ Keluhan nyeri pada sebagian besar pasien yang datang di Poliklinik Rehabilitasi Medik RSUP Prof. Dr. R. D. Kandou Manado ialah nyeri muskuloskeletal berupa nyeri punggung bawah, nyeri leher, dan nyeri rematik. Data di Poliklinik Rawat Jalan Instalasi Rehabilitasi Medik BLU RSUP Prof. Dr. R. D Kandou Manado tahun 2009 menunjukkan jumlah pasien servikalgia sebanyak 138 orang dan sindroma nyeri miofasial sebanyak 8 orang, sedangkan tahun 2010 jumlah penderita servikalgia 169 orang dan sindroma nyeri miofasial sebanyak 12 orang. ${ }^{4}$ Insiden sindrom nyeri miofasial di Amerika Serikat bervariasi antara $30-85 \%{ }^{5}$ Penelitian di Thailand dengan 2.463 subyek mendapatkan 36,2\% mengalami gangguan nyeri muskuloskeletal dengan diagnosis terbanyak sindroma nyeri miofasial. ${ }^{6}$

Beberapa studi epidemiologi menunjukkan bahwa walaupun bukan merupakan kondisi yang fatal sindrom nyeri miofasial merupakan sumber terjadinya disfungsi muskuloskeletal yang menyebabkan penurunan nyata dari kualitas hidup dan penyebab utama kehilangan waktu kerja. ${ }^{5}$

Penelitian yang dilakukan oleh Skootsky tahun 1989 mengatakan bahwa nyeri miofasial pada tubuh bagian atas lebih sering dibandingkan bagian tubuh lainnya. Sebanyak 89\% trigger points terjadi pada empat otot, yaitu: trapesius yang merupakan lokasi tersering (34\%), levator skapulae (19,7\%), infraspinatus, dan skalenus. Secara klinis, kasus sindrom nyeri miofasial servikal mempunyai angka kekambuhan yang sangat tinggi. Gejalagejalanya memengaruhi aktifitas pasien, termasuk kekakuan dan nyeri di leher, serta nyeri kepala yang sering.

Penatalaksanaan nyeri miofasial ditujukan untuk menginaktivasi trigger point dengan menggunakan baik terapi invasif (antara lain: injeksi anestesi lokal, toksin botulinum, dry needling) maupun terapi non-invasif (antara lain: spray and stretch, TENS, ultrasound, laser). Secara umum, penatalaksanaan di atas dapat mencapai penurunan nyeri yang bersifat sementara. Sampai saat ini belum dilaporkan penelitian menggunakan kontrol 
yang menunjang penggunaan terapi di atas dalam mengurangi nyeri trigger points. Beberapa terapi trigger points telah diteliti efektifitasnya. Injeksi dan spray and stretch merupakan terapi umum yang digunakan sebagai terapi trigger points. ${ }^{8-10}$

Terapi spray and stretch telah diaplikasikan dan dideskripsikan oleh Travell dan Simon dengan menggunakan vapoocoolant spray yang dilakukan dalam posisi peregangan otot (stretching). ${ }^{2}$ Stretching dilakukan untuk memanjangkan otot sehingga lingkup gerak sendi meningkat sesuai anatomi bidang gerak. Berlandaskan integrated trigger point hypothesis, tujuan stretching pada terapi sindrom nyeri miofasial sesuai ialah untuk mencegah pemendekan sarkomer pada contrature knots dari trigger point. Pemanjangan sarkomer dengan stretching secara bertahap akan mengurangi tumpang tindih (overlapping) antara molekul aktin dan miosin, sehingga dapat mengurangi kebutuhan energi otot. Bila sarkomer telah mencapai peregangan maksimal, maka tumpang tindih filamen otot akan menjadi minimal dan kebutuhan energi akan menurun, hal ini akan memutuskan krisis energi otot. ${ }^{2}$

Spray membantu peregangan sarkomer untuk membebaskan central trigger point. Dalam bukunya, Travell menggunakan istilah 'stretch is action, spray is distraction'. Vaporized coolant spray (vapocoolant spray) membuat kulit menjadi dingin akibat proses evaporasi yang cepat. Penurunan tiba-tiba suhu kulit merangsang serat saraf sensorik aferen di kulit yang memengaruhi refleks polisinaptik di medula spinalis sehingga menutup gerbang sensasi nyeri dan mencegah refleks hiperstimulasi otot atau sensasi nyeri pada pusat yang lebih tinggi. Pemberian anestesi sementara dilanjutkan dengan peningkatan stretching pasif otot yang berefek terapi langsung pada trigger point dan mengembalikan panjang otot menjadi normal. Ketika ice atau vaporized coolant spray diaplikasikan pada suatu area tubuh, laju metabolik dan inflamasi akan berkurang. $^{2}$ Vasokontriksi menyebabkan penurunan aliran darah pada area tersebut. Otot tidak berkontraksi lama karena penurunan laju metabolik. Pendinginan akan memulihkan spasme otot dan aktifitas saraf juga akan berkurang. Pada terapi trigger point dan spasme otot, vaporized coolant spray digunakan untuk memulihkan nyeri dan spasme otot. Kerja vapocoolant spray yang efektif disebabkan oleh: 1) Stimulasi shock dingin yang ekstrim dan cepat dalam mengubah suhu kulit; 2) Menekan reseptor kulit secara langsung; 3) Berefek serupa dengan light stroking massage. $^{2}$

Dengan demikian, hilangnya nyeri pada spray and stretch merupakan hasil inhibisi spinal dimana stimulasi dingin akan menimbulkan refleks spasme dan memfasilitasi otot untuk meregang dan pada saat otot meregang akan memblok nyeri yang disebabkan oleh trigger points. ${ }^{2,11}$

\section{METODE PENELITIAN}

Penelitian ini merupakan penelitian eksperimental dengan metode pre and post study yang dilaksanakan di Instalasi Rehabilitasi Medik BLU RSU Prof. Dr. R. D. Kandou Manado selama bulan Juni dan Juli 2012.

Subyek penelitian ialah pasien sindrom nyeri miofasial otot trapezius atas, baik yang datang sendiri maupun dirujuk ke Instalasi Rehabilitasi Medik BLU RSU Prof. Dr. R. D. Kandou yang memenuhi kriteria inklusi sebagai berikut: laki-laki atau perempuan berusia 18-65 tahun dengan sindrom nyeri miofasial trapesius atas; terdapat minimal 1 trigger point pada daerah otot trapesius atas; nyeri dengan intensitas sedang sampai berat (VAS $\geq 4$ ) ; dan bersedia mengikuti penelitian serta menandatangani formulir persetujuan. Kriteria eksklusi yaitu bila terdiagnosis adanya keganasan, diabetes melitus, penyakit sirkulasi pembuluh darah yang buruk (Sindrom Raynaud, Penyakit Buerger), luka terbuka, kulit yang sensitif di daerah yang akan diterapi, serta tidak bersedia diikutsertakan dalam penelitian. 
Yang termasuk kriteria drop out yaitu bila tidak mengikuti terapi sebanyak dua kali berturut-turut.

Mula-mula dilakukan pencatatan usia, diagnosis, dan riwayat gejala sindrom nyeri miofasial, kemudian ditentukan titik trigger point pada otot trapezius atas dengan memberi tanda $\mathrm{x}$, serta menilai rasa nyeri dengan skala visual analog scale (sebagai nilai VAS awal). Cara melakukan prosedur spray and stretch pada sindrom nyeri miofasial otot trapezius atas ialah: (1) pasien duduk nyaman dan relaks pada kursi, (2) tangan sisi sakit memegang bawah kursi untuk fiksasi, (3) kulit disemprot dengan chlorethyl sepanjang otot trapezius atas dan nyeri rujukan dengan arah sejajar (tidak overlapping) sebanyak 3-4 kali sapuan, (4) setelah semprotan pertama, secara perlahan dan bertahap dilakukan stretching otot trapezius atas dari tengah otot ke arah origo dan insertio dan dipertahankan selama 10-15 detik, (5) semprotan diteruskan sampai ke nyeri rujukan. Langkah ke-3 hingga ke-5 diulang sebanyak tiga kali dan lama terapi untuk masing-masing sisi leher sekitar 5 menit. Kriteria keberhasilan terapi spray and stretch ialah terjadinya penurunan skala VAS sesudah dilakukan terapi. Penilaian dilakukan setiap hari selama 5 hari.

\section{HASIL PENELITIAN}

Berdasarkan jenis kelamin, jumlah subyek penelitian perempuan lebih besar daripada laki-laki dengan ratio 1:0,7 (Tabel 1). Rerata usia subyek penelitian 43,7 tahun (SD $\pm 11,18$ tahun) dengan usia terendah 25 tahun dan usia tertinggi 61 tahun.

Ditinjau dari tingkat pendidikan, sebagian besar subyek penelitian berpendidikan tingkat SLTA/STM (47,05\%), dengan tingkat pendidikan terendah SLTP dan pendidikan tertinggi Perguruan Tinggi (Tabel 2). Berdasarkan distribusi jenis pekerjaan, sebagian besar subyek penelitian bekerja sebagai karyawan 41,2\% (Tabel 3).
Tabel 1. Distribusi subyek penelitian menurut jenis kelamin

\begin{tabular}{cc}
\hline Jenis kelamin & Frekuensi \\
\hline Perempuan & $10(58,82 \%)$ \\
Laki-laki & $7(41,17 \%)$ \\
\hline
\end{tabular}

Tabel 2. Distribusi subyek menurut tingkat pendidikan

\begin{tabular}{cc}
\hline Tingkat pendidikan & Frekuensi \\
\hline Perguruan Tinggi & $7(41,18 \%)$ \\
SLTA/STM & $8(47,05 \%)$ \\
SLTP & $2(11,77 \%)$ \\
\hline
\end{tabular}

Tabel 3. Distribusi subyek menurut jenis pekerjaan

\begin{tabular}{cc}
\hline Pekerjaan & Frekuensi \\
\hline IRT & $4(23,5 \%)$ \\
Karyawan & $7(41,2 \%)$ \\
Pensiunan & $1(5,9 \%)$ \\
PNS & $3(17,6 \%)$ \\
Wiraswasta & $2(11,8 \%)$ \\
\hline
\end{tabular}

Penilaian VAS pada setiap subyek dilakukan sebanyak 5 kali, yaitu: sebelum terapi spray and stretch pertama (SS I) disebut VAS I; sehari setelah terapi SS I disebut VAS II; sehari setelah terapi spray and stretch kedua (SS II) disebut VAS III; sehari setelah terapi spray and stretch ketiga SS III disebut VAS IV; dan sehari setelah spray and stretch keempat (SS IV) disebut VAS V. Dari hasil penilaian rerata dan median didapatkan penurunan nilai VAS telah terjadi sejak VAS II (Tabel 4).

Hasil uji kenormalan data kelima VAS dengan uji Kolmogorov-Smirnov menyatakan semua data VAS tidak menyebar normal $(P<0,05)$ (Tabel 5).

Untuk pengujian pengaruh terapi spray and stretch terhadap nyeri dilakukan uji Friedman dengan nilai chi-square $=59,503$ dan $P=0,000$ (Tabel 6). Hasil ini menunjukkan terdapat perbedaan yang sangat bermakna dari kelima VAS $(P<$ 0,01). Untuk mengetahui apakah VAS I berbeda dengan VAS II, III, IV, dan V maka diuji lanjut dengan multiple comparisons tests (Tabel 7). 
34 Jurnal Biomedik (JBM), Volume 6, Nomor 1, Maret 2014, hlm. 30-36

Tabel 4. Data statistik Visual Analog Scale (VAS)

\begin{tabular}{lccccc}
\hline & VAS I & VAS II & VAS III & VAS IV & VAS V \\
\hline Rerata & 7,88 & 6,82 & 6,24 & 5,94 & 5,24 \\
Median & 8,00 & 6,50 & 6,50 & 5,50 & 5,00 \\
Minimum & 7 & 5 & 5 & 4 & 4 \\
Maksimum & 9 & 8 & 8 & 7 & 5 \\
\hline
\end{tabular}

Tabel 5. Hasil uji kenormalan data

\begin{tabular}{ccc}
\hline VAS & Nilai statistik & Nilai kemaknaan \\
\hline VAS I & 0,273 & 0,002 \\
VAS II & 0,292 & 0,000 \\
VAS III & 0,258 & 0,004 \\
VAS IV & 0,232 & 0,016 \\
VAS V & 0,213 & 0,039 \\
\hline
\end{tabular}

Tabel 6. Hasil uji Friedman

\begin{tabular}{lcccccc}
\hline & VAS I & VAS II & VAS III & VAS IV & VAS V & chi-square \\
\hline $\mathrm{N}$ & 17 & 17 & 17 & 17 & 17 & \\
Rerata & 7,88 & 6,82 & 6,24 & 5,94 & 5,24 & \\
Median & 8,00 & 7,00 & 6,00 & 6,00 & 5,00 & \\
Rank & 4,97 & 3,71 & 2,71 & 2,24 & 1,38 & $59,503(P=0,000)$ \\
Minimum & 7 & 5 & 5 & 4 & 4 & \\
Maximum & 9 & 8 & 8 & 7 & 6 & \\
\hline
\end{tabular}

Tabel 7. Hasil uji lanjut dengan multiple comparisons tests

\begin{tabular}{cccc}
\hline Perbandingan & $q=\frac{R_{V A S j}-R_{V A S 1}}{S E}$ & qtabel & Kemaknaan \\
\hline VAS I dan VAS II & 2,32 & $\mathrm{q} 0,05 ; 5=3,858$ & $\begin{array}{c}\text { Tidak berbeda bermakna } \\
(P>0,05) \\
\text { Berbeda bermakna } \\
(P<0,05)\end{array}$ \\
VAS I dan VAS III & 4,176 & $\mathrm{q} 0,05 ; 5=3,858$ & $\begin{array}{c}\left(\begin{array}{c}\text { Berbeda sangat bermakna } \\
(P<0,01)\end{array}\right. \\
\text { VAS I dan VAS IV }\end{array}$ \\
VAS I dan VAS V & 5,045 & $\mathrm{q} 0,01 ; 5=4,603$ & $\begin{array}{c}\text { Berbeda sangat bermakna } \\
(P<0,01)\end{array}$ \\
\hline
\end{tabular}

Uji lanjut dengan multiple comparisons tests (Tabel 7) menyatakan:

1. Tidak terdapat perbedaan bermakna antara VAS I dan VAS II $(P>0,05)$, yang menunjukkan terapi spray and stretch belum menurunkan nyeri.

2. Terdapat perbedaan bermakna antara VAS I dan VAS III $(P<0,05)$, yang menunjukkan terapi spray and stretch dapat menurunkan nyeri pada hari ke-2.
3. Terdapat perbedaan sangat bermakna antara VAS I dan VAS IV $(P<0,01)$, yang menunjukkan terapi spray and stretch dapat menurunkan nyeri pada hari ke-3.

4. Terdapat perbedaan sangat bermakna antara VAS I dan VAS V $(P<0,01)$, yang menunjukkan terapi spray and stretch dapat menurunkan nyeri pada hari ke-4. 


\section{BAHASAN}

Jumlah subyek penelitian 17 orang, terdiri dari 10 perempuan dan 7 laki-laki (Tabel 1). Hal ini mengindikasikan bahwa insiden nyeri miofasial lebih tinggi pada perempuan daripada laki-laki. Keefe (2000) menyatakan pada perempuan didapatkan level nyeri dan disabilitas fisik yang lebih tinggi serta menunjukkan perilaku nyeri berbeda daripada laki-laki. Berdasarkan penelitian yang dilakukan Delgado (2009) juga didapatkan insidensi nyeri miofasial yang lebih tinggi pada wanita yaitu sebanyak 54\% sedangkan pada laki-laki 45\%. ${ }^{14,15}$ Menurut sebaran usia subyek, Delgado mendapatkan rentang umur dari 25 hingga 61 tahun dengan nilai rata-rata 43,71 $\pm 11,185$ tahun; hal ini sesuai dengan usia angka kejadian terbanyak nyeri miofasial yaitu 27,5-50 tahun. ${ }^{15}$ Tingkat pendidikan pada penelitian ini yang terbanyak SLTA/STM (47,05\%) dan pekerjaan terbanyak ialah karyawan (41,2\%). Sebagian besar pasien mengatakan penyebab nyeri berhubungan dengan kegiatan sehari-hari misalnya pekerjaan yang menyebabkan ketegangan dan kelelahan otot, postur badan yang buruk (mechanical stress), dan pekerjaan dengan ergonomik yang buruk sehingga mengakibatkan repetitive use pada otot trapesius atas.

Pada penelitian ini dilakukan penilaian VAS sebanyak 5 kali yaitu VAS I-V (Tabel 5). Hasil uji kenormalan data kelima VAS dilakukan dengan uji Kolmogorov-Smirnov dan hasil yang didapatkan menunjukkan semua data VAS tidak menyebar normal ( $P$ $<0,05$ ), sehingga untuk penilaian pengaruh terapi spray and stretch terhadap nyeri dilanjutkan dengan uji Friedman. Hasil uji Friedman memperlihatkan nilai chi-square $=59,503$ dengan $P=0,000$, yang menunjukkan adanya perbedaan VAS yang sangat bermakna pada kelima pengamatan $(P<0,01)$. Untuk mengetahui apakah VAS I berbeda dengan VAS II, III, IV, dan V maka diuji lanjut dengan multiple comparisons tests.

Pada Tabel 7 uji statistik dilakukan atas rerata VAS, didapatkan VAS II, VAS
III, VAS IV, dan VAS V menunjukkan penurunan di bawah VAS I. Uji statistik didapatkan rerata VAS I (sebelum terapi SS I) dan VAS II (setelah terapi SS I) menunjukkan penurunan VAS yang tidak bermakna, sedangkan uji statistik rerata VAS I dan VAS III (setelah terapi SS II) menunjukkan penurunan VAS yang bermakna. Uji statistik rerata VAS I dan VAS IV (setelah terapi SS III), dilanjutkan dengan uji statistik VAS I dan VAS V (setelah terapi SS IV); keduanya menunjukkan penurunan VAS yang sangat bermakna. Perbaikan nilai VAS pada terapi spray and stretch ini sesuai dengan penelitian oleh Jaeger (1986) dan Hong (2004) mengenai terapi spray and stretch pada nyeri miofasial otot trapesius atas dengan hasil menunjukkan perbaikan VAS dan pressure threshold meter (PTM). ${ }^{15-17}$ Yagci (2004) menggunakan intervensi spray and stretch pada nyeri miofasial servikal selama enam sesi dengan hasil terdapat perbaikan nilai VAS. ${ }^{13,14}$ Jaeger (1986) menyimpulkan bahwa efektifitas terapi spray and stretch dalam mengurangi intensitas nyeri dan meningkatkan pressure pain threshold bukan disebabkan oleh efek anestesi vapocoolant spray karena vapocoolant spray tidak menghasilkan anestesia di jaringan subkutan dan otot karena ketebalan jaringan tersebut. ${ }^{16}$ Berkurangnya nyeri disebabkan oleh peregangan otot yang mengurangi sensitivitas trigger point. Seperti yang dikemukakan oleh Travell, spraying pada permukaan kulit akan menyebabkan terjadinya penurunan suhu kulit secara tiba-tiba yang mengakibatkan anestesi sementara, terjadi relaksasi otot yang memungkinkan dilakukan peregangan pasif untuk menginaktivasi atau menghancurkan trigger point di dalam otot tersebut. ${ }^{2}$ Teknik spray and stretch mengunakan vapoocolant sebagai counter irritant terhadap nyeri miofasial akibat spasme otot dan trigger point. ${ }^{5,12}$

\section{SIMPULAN}

Dari hasil penelitian dapat disimpulkan bahwa terapi spray and stretch 
sebaiknya dilakukan minimum sebanyak dua kali kunjungan terapi selama kurang lebih 10 menit pada otot trapesius setiap kunjungan untuk memperoleh hasil penurunan VAS yang bermakna.

Terapi spray and stretch merupakan terapi yang efisien dalam hal waktu dan tenaga serta mudah dan praktis yang dapat digunakan untuk menurunkan nyeri miofasial otot trapesius atas.

\section{SARAN}

Disarankan untuk lebih memanfaatkan terapi spray and stretch pada penanganan nyeri miofasial. Juga diperlukan penelitian lanjutan dengan menggunakan kontrol untuk mengetahui efektifitas terapi spray and stretch dan penelitian banding dengan efektifitas dry needling pada terapi nyeri miofasial.

\section{DAFTAR PUSTAKA}

1. Simons DG. Myofascial pain syndrome due tue trigger point. In: Goodgold J, editor. Rehabilitation Medicine. St Louis: CV Mosby Company, 1988; p. 686-723.

2. Simons DG, Travell JG, Simons LS. Myofascial Pain and Dysfunction: The Trigger Point Manual Volume 1 Upper Half Body (Second Edition). Baltimore: Williams \& Wilkins, 1983; p. 45-102, 183-201.

3. Thamrinsyam $\mathbf{H}$. Myofascial trigger point syndrome. In: Advanced Continuing Education Ilmu Kedokteran Fisik dan Rehabilitasi. Surabaya: Bagian Rehabilitasi Medik Universitas Airlangga, 1991: p. 45-72.

4. Data Rekam Medik Poliklinik Rawat Jalan Instalasi Rehabilitasi Medik BLU RSUP Prof. Dr. R. D. Kandou Manado Tahun 2009-2010.

5. Baldry PE. Myofascial Pain and Fibromyalgia Syndromes. Edinburgh; Churchill Livingstone, 2001; p. 113-8.

6. Fernandez C, Campo MS, Carnerro JF, Miangolarra JC. Myofascial syndrome: Manual therapies in myofascial trigger point treatment: A systematic review. Journal of Bodywork and Movement Therapies. 2005;9:27-34.

7. Skootsky SA, Jaeger B, Oye RK. Prevalence of myofascial pain in general internal medicine practice. West J Med. 1989;151: p. 157-60.

8. Modul Muskuloskeletal. Submodul Tatalaksana Kedokteran Fisik dan Rehabilitasi pada Myofascial Trigger Point Syndrome (MTPS). Jakarta: Kolegium Ilmu Kedokteran Fisik dan Rehabilitasi Indonesia, 2009: p. 14.

9. Huguenin LK. Myofascial trigger points: the current evidence. Physical Therapy in Sport 2004;5:2-12.

10. Walsh NE. Treatment of the patient with chronic pain. In: De Lisa JA: Rehabilitation Medicine: Principle and Practice (Fifth Edition). Philadelphia: Lippincott, 2010: p. 1273-85.

11. Sola AE, Bonica JJ. Myofascial pain syndromes. In : The Management of Pain Vol 1 (Second Edition). Philadelphia: Lea \& Febiger, 1990: p. 352-67.

12. Baldry PE. Acupuncture, Trigger Points and Musculoskeletal Pain (Third Edition). London: Elsevier Churchill Livingstone, 2005; p. 77-151, 204-19.

13. Yagci N, Uygutr F. Comparison of connective tissue massage and spray and stretch technique in the treatment of chronic cervical myofascial pain syndrome. The Pain Clinique. 2004;16(4):469-74.

14. Keefe FJ, Wilkins RH, Cook WA, Crisson JE, Muhlbaier LH. Depression. Pain, and pain behavior. J Consult Clin Psychol 1986;54:665-9.

15. Delgado PL. Common pathways of depression and pain. J Clin Psychiatry 2004;65(Suppl 12);16-9.

16. Jaeger B, Skootsky SA. Doubleblind, controlled study of different myofascial trigger point techniques. Pain 1987;4 (Suppl): 292.

17. Hong CZ. Muscle Pain Syndromes. In: Braddom RL, editor. Physical Medicine and Rehabilitation. Philadelphia: Saunders, 2011; p. 971-96. 